Original Article

\title{
Application of Ultrasonic-Assisted Fractionation with Full-Factorial Design for the Production of Alkaloid-Rich Fraction from Ficus septica Leaves
}

\author{
Muhammad Hafizh Ridho, Andayana Puspitasari Gani, Subagus Wahyuono, Nanang Fakhrudin* \\ 1 Faculty of Pharmacy, Universitas Gadjah Mada, 55281 Yogyakarta, Indonesia \\ * Corresponding author: Nanang Fakhrudin I Email: nanangf@ugm.ac.id
}

Received: 17 October 2020; Revised: 18 November 2020; Accepted: 20 November 2020; Published: 31 December 2020

\begin{abstract}
Ficus septica Burm. F (Awar-awar) in Indonesian herbal medicine traditionally used for the treatment of various disease. Previous studies indicated that the F. septica leaves contained phenantroindolizidine alkaloids with anticancer activity. Fractionation of the ethanol extract of F. septica leaves using n-hexane was able to separate chlorophylls and other inert non-polar constituents from the extract. This fractionation process can be optimized using ultrasonic-assisted fractionation to yield n-hexane insoluble fraction (HIF) that is rich in alkaloids. This study aimed to produce HIF from the ethanol extract of F. septica leaves by using optimized ultrasonic-assisted fractionation with $\mathrm{n}$-hexane as a solvent and full factorial as experimental design. Ficus septica leaves were macerated in ethanol $(60 \%)$ and the extract was used for the ultrasonic-assisted fractionation process. The duration of fractionation (5-30 minutes), the extract : $\mathrm{n}$-hexane ratios (1:0.1 - 1:1.66 ml/ml), and the ultrasonic power (21-106 Wrms) were optimized to determine the optimal condition for each variable. These optimal variables were used for the production of HIF from the extract by using full factorial design in the ultrasonicassisted fractionation process. The total alkaloid content was measured using spectrophotometry and was used as parameter for the optimization process. We found that the optimal condition for the fractionation process based on each single variable optimization were 5 minutes of the fractionation duration, 64-70Wrms of the ultrasonic power, and 1:0.7 - 1:0.8 of the extract : n-hexane ratio. By using these optimized variables, the ultrasonic-assisted fractionation using full factorial design yielded up to $0.035 \%$ total alkaloid content which is almost double from those in the extract $(0.019 \%)$. This study provided a basic experimental model for the production of alkaloid-enriched HIF from F. septica leaves in the industrial or pilot scale, and might contribute to the development of Indonesian herbal medicine products from natural resources.
\end{abstract}

Keywords: Awar-awar; Alkaloid; Anticancer, Herbal medicine, Full Factorial Design

\section{INTRODUCTION}

Currently, cancer is still one of the deadliest diseases in the world because its difficulty to cure and its rapid invasion in the human body. Cancer also represents the disease that most consumes health care budget after heart diseases and kidney failure [1]. Although there are many chemotherapy drugs available in the market for cancer treatment, many studies indicated that the resistance and side toxic effects remained the main problem and accompanied chemotherapy. Resistance and undesired side effects lead to therapeutic ineffectiveness and might reduce the patient quality of life. This encourages the need for alternative chemotherapy agent or co-chemotherapy approach that 
work complementary with chemotherapy to improve therapeutic efficacy and the patient quality of life. Several studies have shown that administering complementary products along with the chemotherapy agents might work synergically or additionally increasing therapeutic efficacy and improving patient quality of life [2-4]. Additionally, the meta-analysis study showed that the use of traditional herbal medicine increased the efficacy of cancer therapy as well as improved the quality of life of cancer patients $[5,6]$.

Indonesia is mega biodiversity country with abundant medicinal plants that have the potential to be developed as traditional medicinal products to treat cancer. One of these potential plants is Ficus septica Burm. F. (Awar-awar). The leaves of F. septica are empirically used for various health problems, such as the treatment of skin diseases, appendicitis, ulcers, rattlesnake bites, warts and shortness of breath [7]. Previous studies demonstrated that the ethanol extracts of F. septica leaves and its fractions showed cytotoxic activity on cancer cells in vivo and in vitro [8,9], and increased cancer cells sensitivity upon the treatment with the chemotherapy agent, doxorubicin [10-12]. The ethanol extract of F. septica leaves has been shown to have a cytotoxic effect on T47D and MCF-7 breast cancer cells, with $\mathrm{IC}_{50}$ of $13 \mu \mathrm{g} / \mathrm{ml}$ and $6 \mu \mathrm{g} / \mathrm{ml}$ respectively [3,14], and it also has antiproliferative effect on breast cancer cells [15]. The low IC $_{50}$ against cancer cells in several experiments indicated that F. septica is a potential source of anticancer agents. The compounds responsible for the anticancer activity of $F$. septica leaves extract are phenanthroindolizidine alkaloids such as tylophorine, 14 $\alpha$-hydroxyisocrebrine N-oxide, ficuseptine A, 14-hydroxy-3,4,6,7tetramethoxyphenanthroindolizidine, 14-hydroxy-2,3,4,6,7-pentamethoxyphenanthroindolizidine, tylocrebrine, isotylocrebrine, antofine, and 2 seco-phenanthroindolizidine alkaloids: septicine, and secoantofine [16-18]. Previous research showed that fractionation of $F$. septica ethanol extract using nhexane resulted in the n-hexane insoluble fraction (HIF) that has a potent cytotoxic activity $[9,12]$. The HIF contained alkaloids and demonstrated cytotoxic activity on cancer cells. It also enhanced the sensitivity of cancer cells against anticancer drug, doxorubicin [11]. However, the aforementioned study did not determine the amount of total alkaloid and the fractionation method has not been optimized. In this study, we optimized the production of the HIF from the ethanol extract of F. septica leaves by using ultrasonic-assisted fractionation method with a full factorial design. N-hexane was used as the solvent of choice for the fractionation process.

Liquid-liquid fractionation using n-hexane was able to remove invaluable substances including chlorophylls, lipids and waxes to yield the HIF [11]. However, conventional fractionation is lack of efficiency and effectivity because it consumes high energy, takes long time duration, and uses excessive solvent [5] and therefore, it is not suitable for industrial application. Ultrasonicassisted fractionation is the commercially available and advance method capable of increasing fractionation yield with less energy and solvent, as well as shorter time duration. In the HIF production, the ultrasonic wave might enhance total alkaloid content by generating mass transfer rapidly and powerfully [6] that can dramatically increase the fractionation effectivity and efficiency. In the ultrasonic-assisted fractionation, the main mechanism is a mass transfer. This fractionation improves effectivity and efficacy by increasing the mass transfer via the intensifying of intermolecule interactions among the solvent and the sample [19]. Additionally, the utilization of ultrasonic power breaks the particles size into smaller parts and increases sample dissolution [20]. The effectivity and efficiency of an ultrasonic-assisted fractionation is influenced by several factors such as solvent ratio, 
fractionation duration, and mechanical strength (energy) [7][8]. Here, we optimized these factors by using a full factorial design approach to obtain an optimal condition for the ultrasonic-fractionation process. Since alkaloids are the active compounds responsible for the anticancer activity in the HIF, thus, the total alkaloid content of the HIF was used as an indicator in the optimization of fractionation process. First, the effects of each single variable (solvent ratio, fractionation duration, and mechanical strength) were investigated, and then the full factorial design of fractionation was employed to investigate the variables yielding the highest alkaloid content.

\section{MATERIALS AND METHODS}

\subsection{Materials}

\subsubsection{Plant Material}

Ficus septica leaves were harvested from Tawangmangu district, Jawa Tengah, Indonesia. The leaves were washed with running water and then let dried at room temperature. The leaves were dried in the oven at temperature of $60^{\circ} \mathrm{C}$ for $48 \mathrm{~h}$, and then cut into a smaller size and powdered to obtain dried powder for the extraction process.

\subsubsection{Chemicals}

The chemicals used in this experiment were Sodium hydroxide (Merck), phosphate buffer saline consist of Sodium phosphate (Merck), and citric acid (Merck), Bromocresol green (Merck), common pro-analytical grade solvents including chloroform and $n$-hexane (Merck), water, and ethanol (technical grade).

\subsubsection{Instrument}

The Ultrasonic-assisted fractionation was done using Lab Ultrasonic for radial probe istrument equipped with Nextgen 750 as power generator (SinapTec). A peristaltic pump BT 100S equipped with a pippet was used to separate the n-hexane insoluble fraction (lower fraction) from the $n$-hexane soluble fraction (upper fraction). A spectrophotometer (Shimadzu UV1800) was used to determine the total alkaloid content. The glass wares consisted of separating funnel (Duran) volumetric flask (Duran), cyclindrical glassware (Iwaki), centrifuge, and sonicator bath, were also used in this research.

\subsection{Methods}

\subsubsection{Plant Extraction}

The dried F. septica leaves powder were extracted in ethanol (60\%) for $12 \mathrm{~h}$. Our preleminary study indicated that the extraction of $F$. septica leaves using $60 \%$ of ethanol produced the highest amount of alkaloid compared to that using the lower and the higher ethanol percentage. The filtrate was separated from the residue using filter filtration on a Buchner funnel. The filtrate was evaporated on a rotary evaporator (IKA), and the evaporation process $\left(60^{\circ} \mathrm{C}\right)$ was terminated when the total solid of the extract reached 35-40\%, measured in a moisture analyzer (Metler Toledo). The extract was collected for the fractionation process.

\subsubsection{Ultrasonic-Assisted Fractination}

The liquid extract of F. septica leaves $(700 \mathrm{~mL})$ with total solid of $35-40 \%$ was put into a cylindrical glassware. N-hexane was used as the solvent to produce the soluble and insoluble fraction. The ultrasonic-assisted fractionation was done by applying ultrasonic power (0-106 Wrms) through the ultrasound radial probe at $20 \mathrm{KHz}$. After the fractionation process was completed, the fractions were let in room temperature for $20 \mathrm{~h}$ until 2 fractions (the lower and upper layer) formed. The upper 
fraction was the n-hexane soluble fraction; whereas the lower was the n-hexane insoluble fraction (HIF). The HIF was used for this study. There were 2 part of this study, first part (One factor one level) and second part (full-factorial design). The purpose of first part of fractiontation was to observe effect of each parameters (duration of fractionation, ratio of extract : hexane, ultrasound power) and full factorial design fractionation used to investigate which parameters have effect to rise total alkaloid content.

\subsubsection{Fractionation duration optimization}

The liquid extract $(350 \mathrm{~mL})$ was stirred until homogenous. The extract was then poured into $700 \mathrm{ml}$ cylindrical glassware, and added with $350 \mathrm{ml}$ of $n$-hexane. The ultrasonic-assisted fractionation was done at the strength of $90 \mathrm{Wrms}$ and ratio of extract : solvent was 1:1. Duration in these fractionation were 5 minutes, 10 minutes, 20 minutes and 30 minutes. The fraction was left in the room temperature for 20 hours before the n-hexane soluble fraction was discarded and the nhexane-insoluble fraction (HIF) was collected. The total alkaloid content was measured using a spectrophotometer at the wavelength of $420 \mathrm{~nm}$.

\subsubsection{Extract : solvent ratio optimization}

The extract added with $n$-hexane with the extract : solvent ratio of $1: 0.1 ; 1: 0.3 ; 1.0 .6 ; 1: 1 ; 1: 1.3$ and 1:1,6 in a 700 cylindrical glassware. The ultrasonic-assisted fractionation was done at the strength of $90 \mathrm{Wrms}$ with the duration obtained from 2.2.3 (5 minutes). The next step was similar to that was described previously in the section 2.2.3.

\subsubsection{Ultrasonic strength optimization}

The extract was added with n-hexane with the volume according to the optimized extract : nhexane ratio obtained from section 2.2.4 (1:0.3) in a $700 \mathrm{ml}$ cylindrical glassware. The ultrasonicassisted fractionation was done at the strength of $21,42,64,85$, and $106 \mathrm{Wrms}$. The duration of the fractionation referred to the optimized fractionation duration obtained from section 2.2.3 (5 minutes).

\subsubsection{Application of factorial design in the fractionation}

To investigate whether each parameter has a significant influence on the fractionation process and to observe interactions among the parameters, factorial design was employed in the study design. Factorial design is the form of design of experimental that consist of planning, analysis, setting and interpretation of data in experiment. Factorial design used factor and level. Factor (parameter) is a observed variable that may impact the result of experiment. Level is value of factor that observed in experiment. If a experiment consist of 2 level, it used low point (-1) and high point (1) [21]. In this experiment, 2 levels and 2 factors were used in the factorial design. The ultrasonic power and the ratio of the extract to the solvent (n-hexane) represented the factors. The ultrasonic power at $42 \mathrm{Wrms}$ (lower point) and at $70 \mathrm{Wrms}$ (higher point), and the extract : solvent ratio of 1:0.1 (lower point), and 1:0.8 (higher point) represented the levels in the factorial design.

\subsection{Spectrophotometry Analysis}

The HIF $(10 \mathrm{ml})$ was centrifuged at $3000 \mathrm{rpm}$ for 10 minutes. This fraction was taken $0.2 \mathrm{~mL}$ into separating funnels and added with BCG $(5 \mathrm{~mL})$ and phosphate buffer $(5 \mathrm{~mL})$. This mixture was partitioned using $5 \times 2 \mathrm{ml}$ of chloroform. The lower fraction was separated and then centifugated at 
$3000 \mathrm{rpm}$ for 5 minutes. The absorbance was measured using a spectrophotometer at the wavelength of $420 \mathrm{~nm}$.

\subsubsection{Preparation of Bromocresol Green (BCG)}

To measure the total alkaloid content in the HIF using spectrofotometry method, bromcresol green was used as a chemical reagent to form alkaloid-bromcresol-green complex for generating a standard curve. This method referred to Shamsa et al and Qarah et al [22][24]. Shortly, bromocresol green $(69,80 \mathrm{mg})$ was dissolved in $3 \mathrm{ml}$ of $\mathrm{NaOH} 2 \mathrm{~N}$ and added with aquadest in a 1000 volumentric flask.

\subsubsection{Preparation of phosphate buffer saline with $\mathrm{pH} 4.7$}

Phosphate buffer saline( $\mathrm{pH} 4.7$ ) was prepared by mixing $2 \mathrm{M}$ sodium phosphate (71.60 $\mathrm{g}$ in $1000 \mathrm{~mL}$ aquadest) with $0.2 \mathrm{M}$ citrit acid (42.02 $\mathrm{g}$ of citrit acid in $1000 \mathrm{~mL}$ aquadest). This mixture was adjusted to $\mathrm{pH}$ of 4.7 .

\subsubsection{Calibration curve for visible spectrophotometer}

Chloroquine phospate $(1 \mathrm{mg})$ was dissolved in $25 \mathrm{ml}$ aquadest and sonicated in the water bath for 10 minutes. Phosphate buffer ( $\mathrm{pH} 4.7$ ) and BCG solution each at the volume of $5 \mathrm{~mL}$ was mixed with the chloroquine phosphate solution (at volume of $0.2 ; 0.4 ; 0.6 ; 0.8 ; 1$ and $1.2 \mathrm{ml}$ ) each in different separating funnels. These mixtures were added with $5 \times 2 \mathrm{ml}$ chloroform in the separating funnels. The lower phase (chloroform fraction) was separated and then centrifugated for 5 minutes at room temperature. The absorbance of the BCG-Chlroquine complex was measured in a spectrophotometer at the wavelength of $420 \mathrm{~nm}$.

\subsubsection{Preparation of phosphate buffer saline with $\mathrm{pH} 4.7$}

Phosphate buffer saline( $\mathrm{pH}$ 4.7) was prepared by mixing $2 \mathrm{M}$ sodium phosphate (71.60 $\mathrm{g}$ in $1000 \mathrm{~mL}$ aquadest) with $0.2 \mathrm{M}$ citrit acid (42.02 $\mathrm{g}$ of citrit acid in $1000 \mathrm{~mL}$ aquadest). This mixture was adjusted to $\mathrm{pH}$ of 4.7 .

\subsection{Statistical Analysis}

The total alkaloid contents among group of treatments were compared using a statistical analysis. First, the data distribution was analyzed using Saphiro-Wilk to determine whether the data distribution is a normal $(\mathrm{P}>0.05)$. To investigates the data homogeneity, Levene test was used $(\mathrm{P}>$ 0.05). Data with normal distribution and homogenous were analyzed by using one-way Anova to determine their significant level $(\mathrm{P}<0.05)$.

\section{RESULT AND DISCUSSION}

Currently the utilization of natural products for the treatment and prevention various diseases, including cancer is gaining many interests. One of the medicinal plants from Indonesian origin is $F$. septica (awar-awar). The leaves of F. septica contain phenantroindolizidine alkaloids that have anticancer activity. There is no established method of alkaloid separation or fractionation from the leaves of F. septica. The common method of separating the compounds of interest from the extract is by fractionation. Ultrasonic-assisted fractionation is an upgrade from conventional or manual 
fractionation aiming to increase the fractionation effectivity and efficiency. The ultrasonic-assisted fractionation has been used by several pharmaceutical industries. This study aimed to produce the alkaloid-enriched fraction (HIF) from the ethanol extract of F. septica leaves using an ultrasonicassisted fractionation with a full factorial design. Several previous studies have shown that ultrasonic-assisted fractionation was able to increase the fractionation effectivity and efficiency due to the increase in temperature, mass transfer, and generation of bubble cavitation mechanism [26][19].

\subsection{Measurement of total alkaloid content using visible spectrophometer}

As a measure in the fractionation process, the total alkaloid content in HIF was used. The total alkaloid content was determined using spectrophotometer. The interaction between alkaloids in HIF and bromocresol green produces alkaloid-bromocresol green complex that can be quantified in a spectrophotometer at the wavelength of $420 \mathrm{~nm}$ [22]. Because the alkaloid components in the F. septica leaves are mainly dominated by phenatroindolizidine alkaloid, chloroquine was used as a compound standard due to structural similarity. The reaction between chloroquine and bromocresol green was used to generate a calibration curve (Figure 1) for determination of total alkaloid content in the HIF.

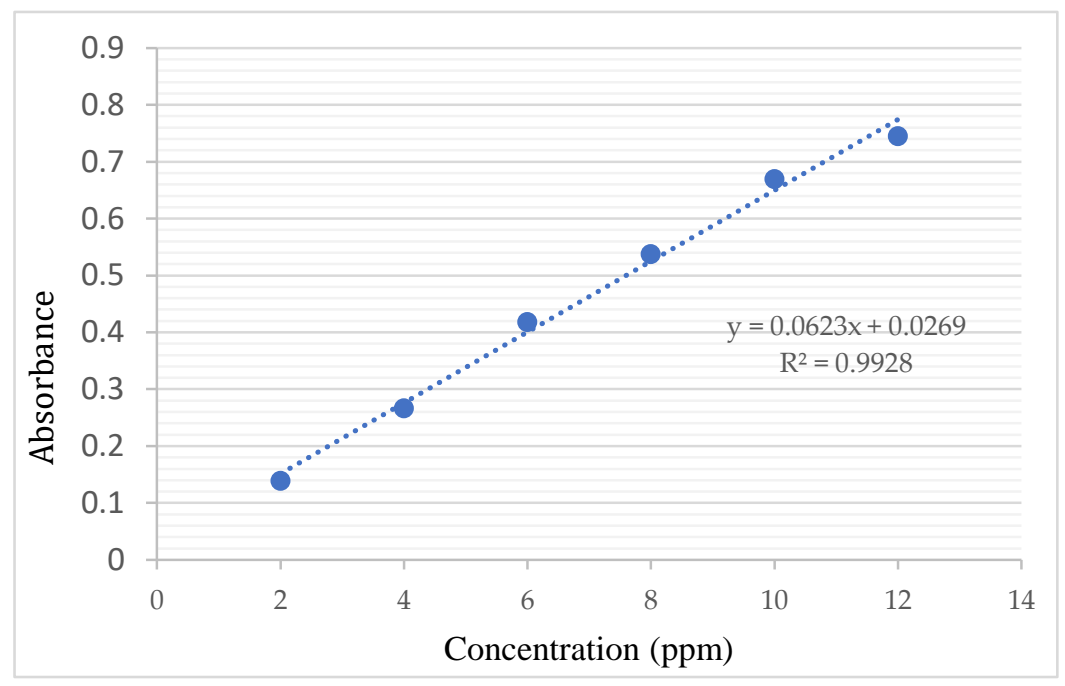

Figure 1. Calibration curves and linear regression equations of chlroquine as a standard for the determination of total alkaloid content using spectrophotometer.

\subsection{The effect of fractionation duration to the total alkaloid content}

Duration of fractionation affects the amount of mass transfer of the compound of interest toward the solvent. On the other hand, longer duration of ultrasonic-assisted fractionation increases temperature which is not good for compund stability. Ultrasonic also lead degradation of substances in HIF. In this study (Figure 2), duration of fractionation had no effect to increases total alkaloid content. Total alkaloid content in HIF were 0.110, 0.093, 0.111, and $0.096 \%$ using 5, 10, 20, and 30 minutes of fractionation duration, respectively. The fractionation duration that was used for the full factorial design was 5 minutes because 5 minutes of ultrasonic-assisted fractionation produced the highest amount of alkalaid content in the HIF. Thus, fractionation duration of 5 minutes was used for the multivariate design ofin this study using minimal fractionation duration (5 minutes). 


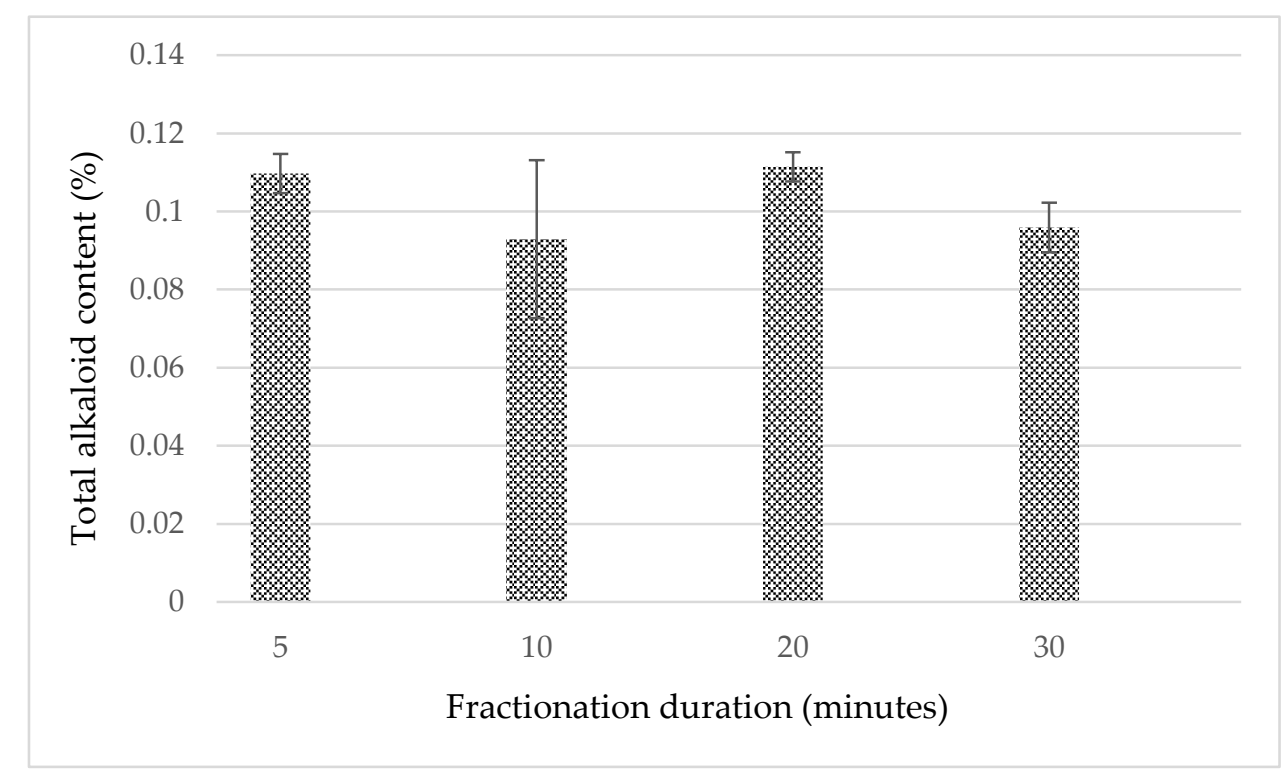

Figure 2. Effect of duration of fractionation to total alkaloid content. Duration of fractionation had no effect to increases total alkaloid content. Total alkaloid content was obtained: $0.110 \%$ (5 min); 0.093\% (10 $\mathrm{min}$ ); $0.1114 \%$ (15 $\mathrm{min})$; and $0.0959 \%$ (30 $\mathrm{min})$.

\subsection{The effect of extract : solvent ratio to the total alkaloid content}

The ethanolic extract of $F$. septica leaves was fractionated with n-hexane in different volumes. The extract : n-hexane ratios were designed at 1:0.1, 1:0.3, 1:0.6, 1:1, 1:1.3, and 1:1.16. In this fractionation process, 3 different solvents comprising ethanol, water, and n-hexane were involved in the fractionation process. Theoritically, $\mathrm{n}$-hexane was an apolar solvent that separated the chlorophylls, lipids, and other inert non polar subsituents from the extract and resulted in the nhexane soluble fraction (HIF) with a higher alkaloid content. However, the amount of n-hexane in the fractionation was not necessarily linear with the total alkaloid content in the HIF. Additionally, the exessive $\mathrm{n}$-hexane increases cost of production. Therefore, the extract : $\mathrm{n}$-hexane ratio required to be optimized as it affects total alkaloid content. We found that the extract : n-hexane ratio of 1:0.1, 1:0.3, 1:0.6, 1:1, 1:1.3, and 1:1.6 yielded the total alkaloid content of 0.020, 0.0270, 0.023, 0.020, 0.022, and $0.018 \%$, respectively (Figure 3). The extract : hexane ratio of 1:0.1 and 1:0.3 significantly increased the total alkaloid content of the HIF. Interestingly, the ratio higher that 1:0.3 until 1:1.6 did not alter total alkaloid content. Therefore, the extract : $\mathrm{n}$-hexane ratio of 1:0.1 (lower point) and 1:0.33 (higher point) were used in the full factorial design to obtain the optimal condition for fractionation that involves several variables. 


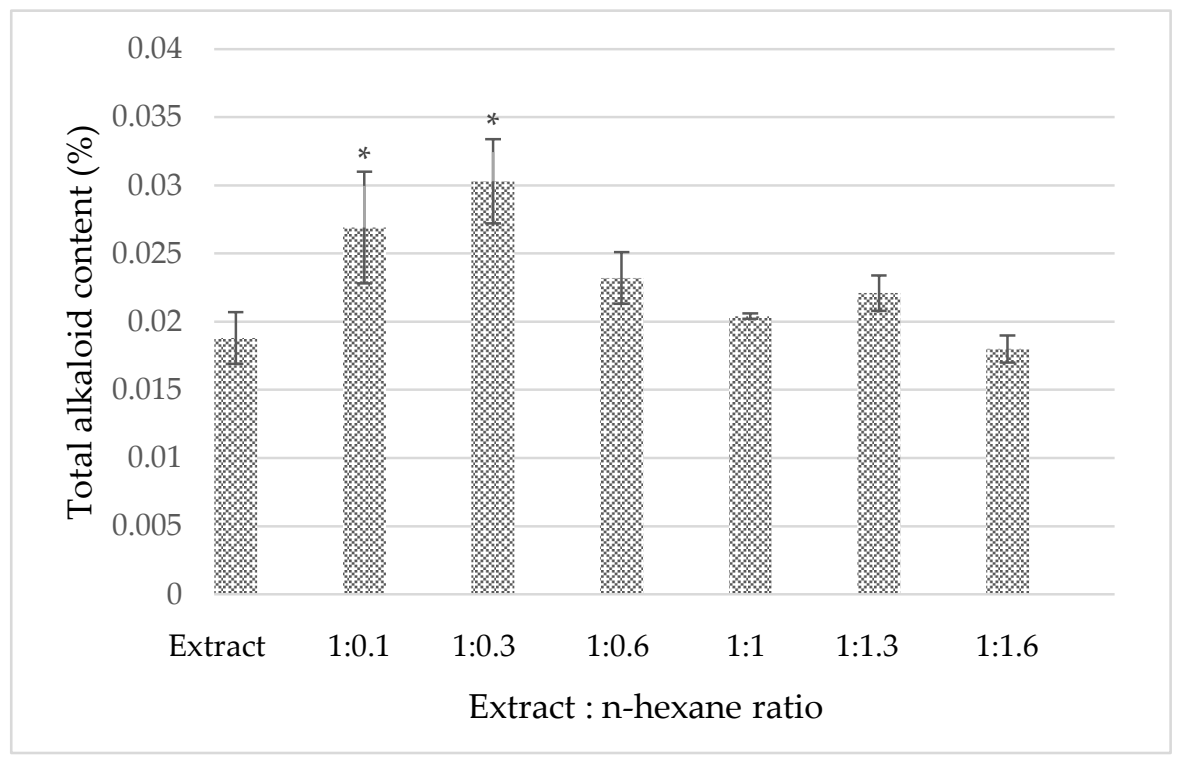

Figure 3. The effect of the extract : solvent ratio to the total alkaloid content. N-hexane was used as a solvent, and the extract : n-hexane ratios were set at 1:0.1 until 1:1.6. The extract : n-hexaneratio of 1:0.1 and 1:0.3 significantly increased the total alkaloid content $\left({ }^{*} \mathrm{P}<0.05\right)$ of the HIF compared to the extract.

\subsection{The effect of ultrasonic power to the total alkaloid content}

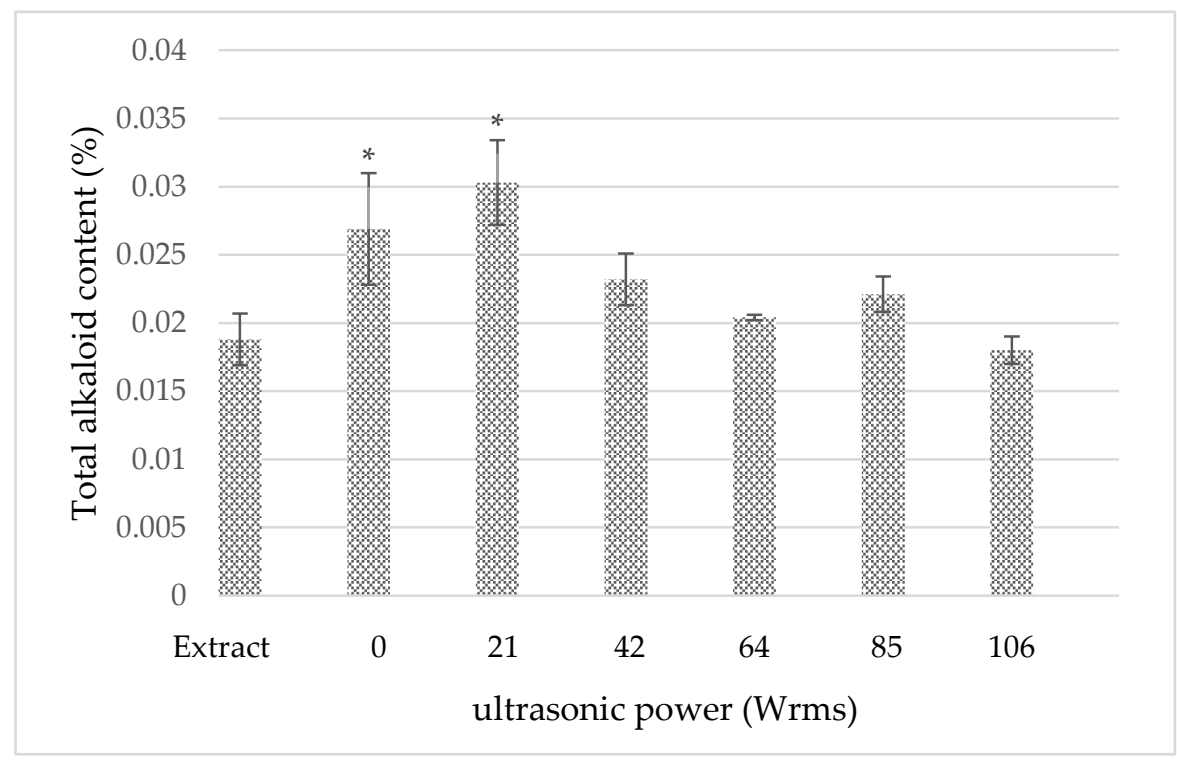

Figure 4. The effect of ultrasonic power to the total alkaloid content in the HIF. The ultrasonic power applied for the fractionation process was ranging 21 to $106 \mathrm{Wrms}$. The total alkaloid content was at peak and showing statistically significant compared to the extract at $64 \mathrm{Wrms}\left({ }^{*} \mathrm{P}<0.05\right)$.

The ultrasonic power applied in the fractionation process affected the yield of the targeted compound by increasing the mass transfer and cavitation to create dynamic stress toward the solvent [23]. In the other hand, the ultrasonic power could raise the temperature leading to the compound destabilization. In this study, for the fractionation process we applied the ultrasonic power of 21, 42, 
64,85 , and 106 Watt root mean square (Wrms) and yielded the total alkaloid content of $0.027,0.028$, $0.032,0.021$, and $0.016 \%$, respectively. Figure 4 demosntrated that the ultrasonic power of 21-106 Wrms, but not higher than $64 \mathrm{Wrms}$ increased the total alkaloid content in the HIF. Nevertheless, the peak of total alkaloid content was reached at $64 \mathrm{Wrms}$. By using $64 \mathrm{Wrms}$ the total alkaloid content of the HIF showed a statistical significant compared to the $0 \mathrm{Wrms}$ (the extract/before fractionation). Consequently, the ultrasonic power of $42 \mathrm{Wrms}$ (lower point) and $70 \mathrm{Wrms}$ (higher point) was applied in the full factorial design.

\subsection{Optimization of total alkaloid content in the insoluble hexane fraction using full-factorial design method}

After the lower (-1) and higher (1) values from each parameters were obtained from the previous single variable optimization, these values were used in the full-factorial design to optimize the condition for the ultrasonic-assisted fractionation of $F$. septica leaves extract. In this study, we used 2 variables (extract : solvent ratio, and ultrasonic power) with 2 levels (the lower point (-1) and the high point (1)), and 1 centre point. From the single variable optimization, we found that the duration of fractionation was 5 minute, the ratio of the extract to n-hexane was 1:0.1 (low point) and 1:0.8 (high point), the ultrasonic power was $42 \mathrm{Wrms}$ (the lower point), and $70 \mathrm{Wrms}$ (the higher point). Table 1 provided the result of the total alkaloid content obtained using the full-factorial design.

Table 1. Total alkaloid content obtained by the full-factorial design. The full-factorial design used 2 levels (the lower point (-1) and the higher point (1)), with 2 variables (extract : n-hexane ratio, and ultrasonic power). In the extract : n-hexane ration, the ratio of 1:0.1 and 1:0.8 were set as the lower and higher point, respectively; whereas in the ultrasonic power, $42 \mathrm{Wrms}$ and $70 \mathrm{Wrms}$ were set as the lower and higher point, respectively. The center point defined the mean between the lower and higher point.

\begin{tabular}{ccccc}
\hline Level & $\begin{array}{c}\text { Ultrasonic } \\
\text { power (Wrms) }\end{array}$ & $\begin{array}{c}\text { Extract : } \mathbf{n}- \\
\text { hexane ratio }\end{array}$ & $\begin{array}{c}\text { Total alkaloid } \\
\text { content (\%) }\end{array}$ \\
\hline $\mathbf{1}$ & 1 & 70 & $1: 0.8$ & $0.031 \pm 0.0042$ \\
$\mathbf{1}$ & 1 & 70 & $1: 0.8$ & $0.035 \pm 0.0008$ \\
$\mathbf{1}$ & 1 & 70 & $1: 0.8$ & $0.033 \pm 0.0025$ \\
$\mathbf{- 1}$ & 1 & 42 & $1: 0.8$ & $0.030 \pm 0.0003$ \\
$\mathbf{- 1}$ & 1 & 42 & $1: 0.8$ & $0.026 \pm 0.0017$ \\
$\mathbf{- 1}$ & 1 & 42 & $1: 0.8$ & $0.025 \pm 0.0008$ \\
$\mathbf{1}$ & -1 & 70 & $1: 0.1$ & $0.030 \pm 0.0011$ \\
$\mathbf{1}$ & -1 & 70 & $1: 0.1$ & $0.026 \pm 0.0010$ \\
$\mathbf{1}$ & -1 & 70 & $1: 0.1$ & $0.023 \pm 0.0013$ \\
$\mathbf{- 1}$ & -1 & 42 & $1: 0.1$ & $0.023 \pm 0.0011$ \\
$\mathbf{- 1}$ & -1 & 42 & $1: 0.1$ & $0.023 \pm 0.0004$ \\
$\mathbf{- 1}$ & -1 & 42 & $1: 0.1$ & $0.025 \pm 0,0011$ \\
$\mathbf{0}$ & 0 & 56.2 & $1: 0.4$ & $0.028 \pm 0.0006$ \\
Extract & & & & $0.019 \pm 0.0010$ \\
\hline
\end{tabular}

Based on the results presented in Table 1, a mathematical equation representing the corelation between the ultrasonic power and extract : $\mathrm{n}$-hexane ratio variables with the total alkaloid content can be described as $0.01883+0.0002 X_{1}-0.00113 X_{2}+0.000311 X_{1} X_{2}+0.00002$ Ct Pt (X: ultrasonic power; $X_{2}$ : extract : $\mathrm{n}$-hexane ratio; and $\left.C t P t=0.0273825\right)$. From this equation, we were able to obtain 
the optimum condition for the production of HIF from the F. septica leaves by using ultrasonicassisted fractionation. The condition were 5 minutes of fractionation duration, (64-70Wrms) of ultrasonic power, and 1:0.7 - 1:0.8 extract : $\mathrm{n}$-hexane ratio. This method yielded up to $0.035 \%$ alkaloid content which is almost double from the total alkaloid content in the extract $(0.019 \%)$. The ultrasonic power, the extract : n-hexane ratio, and the interaction of both variables affected the total alkaloid content in the ultrasonic-assisted fractionation process. These interactions were illustrated as a contour plot in the Figure 5. Each color in Figure 5 represented the total alkaloid content of the HIF produced using different combination of ultrasonic power and extract: n-hexane ratios. The dark green area at the upper right and the dark blue area at the lower left are the highest and lowest alkaloid content. Figure 5 showed that the extract : n-hexane ratio of 1:0.7-1:0.8, and the ultrasonic power of 64-70 Wrms were the optimum fractionation condition to produce HIF with the highest alkaloid content. The total alkaloid content in the HIF obtained using this optimized method is $0.035 \%$ or almost double from the extract. In this study, we found that ultrasonic-assisted fractionation together with the full-factorial design could be used to produce alkaloid-enriched fraction (HIF) from the extract of $F$. septica leaves. These findings provided an important basis for the production of the alkaloid-enriched HIF in the pilot or industrial scales.

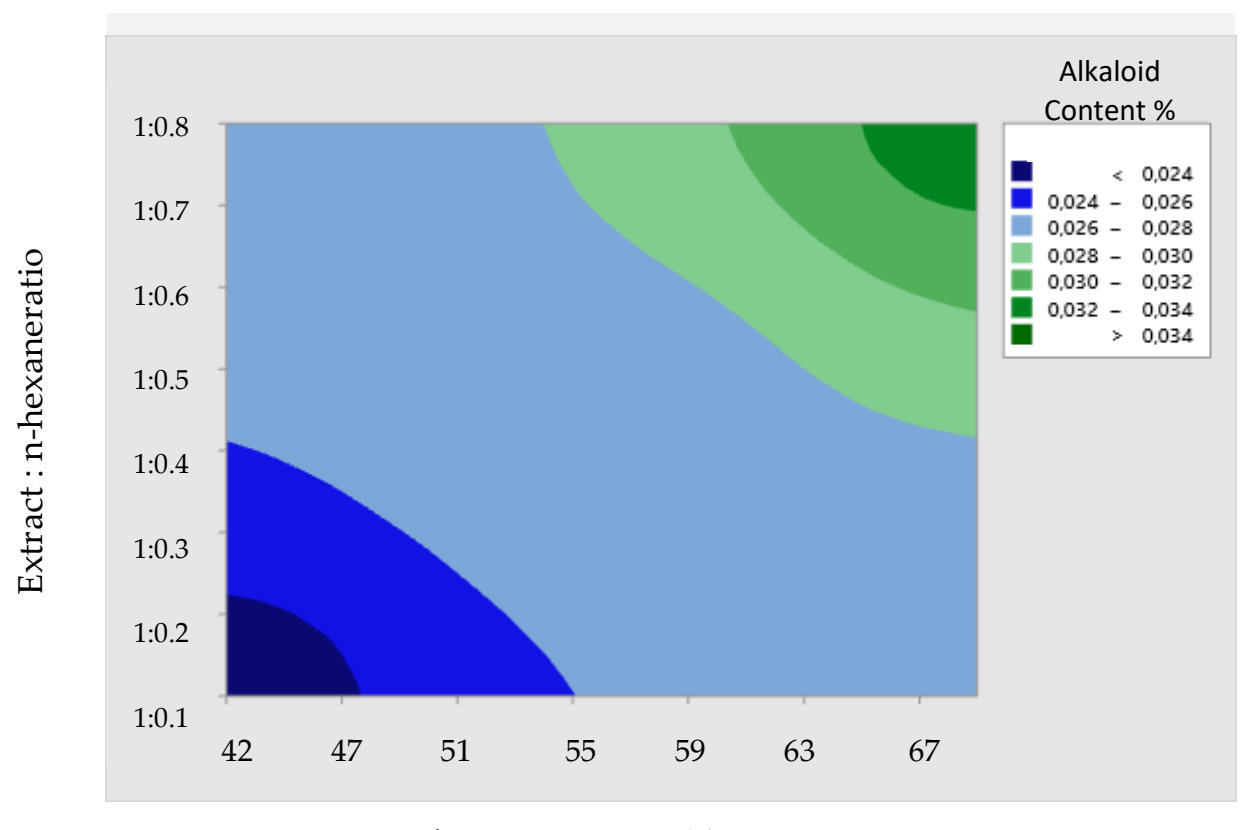

Ultrasonic power (Wrms)

Figure 5. Countur plot showing the effects of the extract : solvent ratio and the ultrasonic power on the total alkaloid content in the HIF production from the F. septica leaves fraction. The optimal condition was obtained at the dark green area (the extract : n-hexane ratio of 1:0.7-1:0.8, and the ultrasonic power of 64-70 Wrms.

\section{CONCLUSION}

This study demonstrated that the ultrasonic-assisted fractionation along with the full factorial design optimization can be used to produce HIF with enriched alkaloid from the extract of F. septica leaves. This method enriched the alkaloid content almost double than the extract and provided a scientific basis for the further production in larger scale.

Funding: This research was funded by Program Riset Inovatif Produktif (RISPRO) Invitasi LPDP Batch II Tahun 2019 (Grant number KEP-85/LPDP/2019). 
Acknowledgments: Authors would like to thank to PT Konimex Pharmaceutical Laboratories, Sukoharjo, Jawa Tengah, for providing laboratory facilities and guidance. The data presented in this study was used by MHR for his undergraduate thesis (skripsi).

Conflicts of interest: The authors declare no conflict of interest.

\section{References}

1. Klaim BPJS untuk Gagal Ginjal Capai Rp 2 Triliun dan Jantung Rp 8 Triliun Jakarta2015 . Available online: https://ifestyle.kompas.com/read/2015/12/29/200000023/klaim.bpjs.untuk.gagal.ginjal.capai.rp.2.triliun.da n.jantung.rp.8.triliun (accessed on 11 October 2020).

2. Hung, K.F.; Hsu, C.P.; Chiang, J.H.; Lin, H.J.; Kuo Y.T.; Sun, M.F.; et al. Complementary Chinese herbal medicine therapy improves survival of patients with gastric cancer in Taiwan: A nationwide retrospective matched-cohort study. Journal of Ethnopharmacology 2017, 199, 1-20.

3. Kuo, Y.T.; Liao, H.H.; Chiang, J.H.; Wu, M.Y.; Chen, B.C.; Chang, C.M.; et al. Complementary Chinese Herbal Medicine Therapy Improves Survival of Patients With Pancreatic Cancer in Taiwan: A Nationwide Population-Based Cohort Study. Integrative Cancer Therapies 2018, 17, 1-12.

4. Wang, S.; Lin. H.; Cong, W. Chinese Medicines Improve Perimenopausal Symptoms Induced by Surgery, Chemoradiotherapy, or Endocrine Treatment for Breast Cancer. Frontiers in pharmacology 2019, 10, 1-16.

5. Kim, W.; Lee, W.B.; Lee, J.W.; Min, B.I.; Baek, S.K.; Lee, H.S.; et al. Traditional herbal medicine as adjunctive therapy for breast cancer: A systematic review. Complementary Therapies in Medicine 2015, 23, 1-22.

6. Sun, X.; Zhang, X.; Nian, J.Y.; Guo, J.; Yin, Y.; Zhang, G.L.; et al. Chinese Herbal Medicine as Adjunctive Therapy to Chemotherapy for Breast Cancer: A Systematic Review and Meta-Analysis. Evidence-based Complementary and Alternative Medicine 2016, 16, 1-20.

7. Sari, N. Etnobotani Tumbuhan Yang digunakan Dalam Pengobatan Tradisional di Kecamatan Sinjai Selatan Kabupaten Sinjai Sulawesi Selatan. Bachelor Degree Thesis, Universitas Islam Negeri Makassar, Makasar, 24 August 2017.

8. Septhea, D.B.; Anindyajati, A.; Darma, A.P.; Nurzijah, I.; Nugroho, A.E.; Meiyanto, E. Ficus septica Burm. F. Leaves Ethanolic Extract Induces Apoptosis in 7,12-Dimethylbenz[A]Nthracene-Induced Rat Liver Cancer Quatitavely. Indonesian Journal of Cancer Chemoprevention 2011, 2, 2, 255-60.

9. Nugroho, A.E.; Ikawati, M.; Hermawan, A.; Putri, D.D.P.; Meiyanto, E. Cytotoxic Effect of Ethanolic Extract Fractions of Indonesia Plant Ficus septica Burm. F. on Human Breast Cancer T47D cell lines. International Journal of Phytomedicine 2011, 2, 2, 255-260.

10. Nugroho, A.E.; Hermawan, A.; Putri, D.P.; Meiyanto, E.; Hakim, L. Synergistic Effects of Ethyl Acetate Fraction of Ficus septica Burm. f. and Doxorubicin Chemotherapy on T47D Human Breast Cancer Cell Line. Journal of Chinese Integrative Medicine 2012, 10, 10, 1162-70.

11. Nugroho, A.E.; Hermawan, A.; Putri, D.D.; Novika, A.; Meiyanto, E.; Kawaichi, M.; Combinational effects of Hexane Insoluble Fraction of Ficus septica Burm. F. and Doxorubicin Chemotherapy on T47D Breast Cancer Cells. Asian Pacific Journal of Tropical Biomedicine 2013, 3, 297-302.

12. Nugroho, A.E.; Akbar, F.F.; Wiyani, A.; Sudarsono. Cytotoxic Effect and Constituent Profile of Alkaloid Fractions from Ethanolic Extract of Ficus septica Burm. f. Leaves on T47D Breast Cancer Cells. Asian Pacific Journal of Cancer Prevention 2015, 16, 16, 7337-42. 
13. Sekti, D.A.; Mubarok, M.F.; Armandani, I.; Junedy, S.; Meiyanto, E. Awar-awar (Ficus septica Burm.f.) Etahnolic Extract Induced Apoptosis of MCF-7 Cells By Downregulation of Bcl-2. Majalah Obat Tradisional 2010, 15, 3, 100-104.

14. Nurcahya, B.M. Efek Antiproliferatif Ekstrak Etanolik Daun Awar-Awar (Ficus septica Burm.F.) terhadap Sel Kanker Payudara T47D. Bachelor Degree Thesis, Universitas Gadjah Mada, Yogyakarta, 2007.

15. Mubarok, M.F.; Arum, D.; Wulandari, A.; Septisetyani, E.P.; Meiyanto, E. Peningkatan Aktivitas Sitotoksik Doxorubisin terhadap Sel Kanker Payudara MCF-7 menggunakan Ekstrak Etanolik Daun Awar-awar (Ficus Septica Burm. F), . Kongres Ilmiah XVI Ikatan Sarjana Farmasi Indonesia; 2008; Yogyakarta.

16. Ueda, J-y.; Takagi, M.; Shin-ya, K.; Aminocaprophenone- and Pyrrolidine-Type Alkaloids from the Leaves of Ficus septica. Journal of Natural Products 2009, 72, 12, 2181-3.

17. Lansky, E.P.; Paavilainen, H.M.; Pawlus, A.D.; Newman, R.A. Ficus spp. (fig): ethnobotany and potential as anticancer and anti-inflammatory agents. Journal of Ethnopharmacology 2008, 119, 2, 195-213.

18. Pratama, N.P..; Wulandari, S.; Nugroho, A.E.; Fakhrudin, N.; Astuti, P.; Sudarsono. Tylophorine Abrogates G2/M Arrest Induced by Doxorubicine and Promotes Increased Apoptosis in T47D Breast Cancer Cells. Asian Pacific Journal of Cancer Prevention 2018, 19, 11, 3065-9.

19. Garcia, A.; Alriols, M.G.; Liaon-Ponte.; Labidi, J. Ultrasonic-Assisted Fractionation of the Lignocellulosic Material, Biosource Technology 2011, 102, 6326-6330.

20. Tao, Y.; Wu, Y.; Han, Y.; Chemat, F.; Li, D.; Show, P.L. Insight into Mass Transfer during UltrasonicEnhanced Adsoprtion/Desorption of Blueberry Antocyanins on Macroporous Resins by Numerical Simulation Considering Ultrasonic Influence on Resin Properties. Chemical Engineering Journal 2020, 380, 113.

21. Mandal, S.C.; Mandal, V.; Das AK, Innovative Extraction Process Design and Optimization Using Design of Experiment Approach, Essential of Botanical Extraction. Academic Press, Cambridge, United Kingdom, 2015; pp 137-163.

22. Shamsa, F.; Monsef, H.; Ghamooshi, R.; Verdian-rizi, M. Spectrophotometric Determination of Total Alkaloid in Some Iranian Medicinal Plant. Journal of Pharmaceutical Sciences Thailand 2008, 32, 17-20.

23. Vinatoru, M. An Overview of the Ultrasonically-assisted Extraction of Bioactive Principles from Herbs. Ultrasonic Sonochemistry 2001, 8, 303-313.

24. Qarah, N.; Basavaiah, K.; Swamy, N. Sensitive and Selective Extraction Free Spectrophotometric Assay of Chloroquine Phospate in Pharmaceuticals Based on Ion-Pair Reaction with Bromocresol Green and Bromocresol Purple. Pharmaceutical Analytica Acta 2017, 8, 3, 1-9.

25. Albu, S.; Joyce, L.; Paniwnyk.; Lorimer, J.P.; Mason, T.J. Potential for the Use of Ultraound in the Extraction of Antioxidant from Rosmarinus officnalis for the Food and Pharmaceutical Indusry. Ultrasonic Sonochemistry 2004, 11, 261-265.

26. Ebringenova, A.; Hromadkova, Z. Effect of Ultrasonic on Extrability of Corn Bran Hemicelluloses. Ultrasonic Sonochemistry 2002, 9, 225-229.

(C) 2020 by the authors. Submitted for possible open access publication under the terms and conditions of the Creative Commons Attribution (CC BY) license (http://creativecommons.org/licenses/by/4.0/). 